\title{
Coralivoría del gasterópodo Jenneria pustulata (Ovulidae: Pediculariinae) en dos arrecifes coralinos del PNN isla Gorgona.
}

\section{Corallivory of the gastropod Jenneria pustulata (Ovulidae: Pediculariinae) in two coral reefs at Gorgona Island NNP.}

\author{
Mauro Giovanni Zucconi, Levy D. Obonaga and Edgardo Londoño-Cruz \\ iD $0000-0002-4925-2298 \quad$ (iD) $0000-0001-8329-9359 \quad 0000-0001-5762-9430$
}

Universidad del Valle, Departamento de Biología, Grupo de Investigación en Ecosistemas Rocosos Intermareales y Submareales Someros-LITHOS, Apartado aéreo 25360,Cali,Colombia.mauro.zucconi@correounivalle.edu.co,levy.obonaga@correounivalle.edu.co,edgardo.londono@correounivalle.edu.co

\section{RESUMEN}

$\mathrm{L}$ os arrecifes coralinos son ecosistemas importantes y altamente biodiversos; estos son afectados por diversos procesos, entre ellos la coralivoría, proceso que consiste en el consumo directo de tejido coralino por parte de un depredador. Es poco el conocimiento existente sobre los efectos de los invertebrados sobre los arrecifes del Pacífico colombiano, es por esto que el objetivo de la presente investigación fue determinar la densidad y tasa de coralivoría de Jenneria pustulata en los arrecifes La Azufrada y Playa Blanca (Isla Gorgona, Colombia). Los caracoles se buscaron y colectaron activamente bajo colonias coralinas, siendo medidos para determinar su estructura de tallas para cada arrecife. Adicionalmente, se realizó una fase de laboratorio en la cual se midió el consumo de tejido coralino de $J$. pustulata durante $24 \mathrm{~h}$, para ambos arrecifes. La talla promedio de J. pustulata fue de de $19.56 \pm 4.71 \mathrm{~mm}$ en La Azufrada y $20.53 \pm 3.40 \mathrm{~mm}$ en Playa Blanca. La talla promedio y la tasa de consumo de tejido coralino fueron estadísticamente diferentes $(\mathrm{P}=0.0001$; $\mathrm{P} \ll 0.001)$ entre los arrecifes. Aunque las tasas de coralivoría se encuentran por debajo de las reportadas para otras especies de moluscos coralívoros, se sugiere continuar con los estudios para comprender la biología de $J$. pustulata; las dinámicas bióticas y abióticas que le afectan y además, entender su efecto sobre los arrecifes de la Isla Gorgona.

PALABRAS CLAVE: Pacífico colombiano, Arrecife de coral, Gastrópoda, Consumo de tejido coralino, Jenneria pustulata.

\section{ABSTRACT}

$\mathrm{C}$ oral reefs are very important and highly biodiverse ecosystems that are exposed to various stressors, including biological ones, such as parasitism and corallivory - the direct consumption of coral tissue by a predator. Knowledge on the effects of corallivory on the coral reefs in the Colombian Pacific is poor. Therefore a study was set up to quantify the abundance of and the corallivory rate by the snail Jenneria pustulata in La Azufrada and Playa Blanca coral reefs (Gorgona Island, Colombia). Snails were manually sampled from the underside of Pocillopora sp. colonies and measured in situ to determine their size structure for each reef. To measure possible damage caused by corallivory, several snails were kept under controlled laboratory conditions for $24 \mathrm{~h}$. Snail sizes and corallivory varied significantly between reefs $(\mathrm{P}=0.0001 ; \mathrm{P} \ll 0.001)$. Snails from Playa Blanca were larger than snails from La Azufrada, while corallivory was higher in La Azufrada than in Playa Blanca. Although corallivory rates by J.pustulata are smaller than rates reported for other predators in different coral species, it is recommended to continue this kind of investigations in order to increase the knowledge on biological dynamics of this species and to understand how they affect the reefs at Gorgona Island.

KEYWORDS: Colombian Pacific, Coral reef, Gastropod, Coral tissue consumption, Jenneria pustulata.

DOI: 10.25268/bimc.invemar.2018.47.2.744

Publicado por INVEMAR

Este es un manuscrito de acceso abierto bajo la licencia CC

Published by INVEMAR

Reconocimiento-No Comercial-Compartir Igual 


\section{INTRODUCCIÓN}

Los arrecifes coralinos son bio-construcciones (i.e. estructuras construidas por organismos) que aportan gran variedad de micro-habitas a diferentes especies de peces e invertebrados marinos (Cumming, 1999; Alvarez-Filip y Gil, 2006), por lo cual son considerados como uno de los ecosistemas con mayor diversidad biológica en todo el mundo (Rotjan y Lewis, 2008), una característica que le confiere a los ecosistemas alta resiliencia (Valiente-Banuet et al., 2015). A pesar de ello, estos ecosistemas son vulnerables a amenazas de tipo biótico, e.g. bioerosión causada por diversas especies de peces, anélidos, crustáceos, equinodermos y moluscos (Glynn y Enochs, 2008) como a factores de tipo abiótico, e.g. cambios en la temperatura (que puede causar blanqueamiento), mareas bajas extremas (que generan mortalidad de corales y otros organismos asociados) y tormentas (que causan daño físico al andamiaje arrecifal). En adición, se pueden ver afectados por actividades humanas como pesca excesiva, contaminación de las aguas y extracción manual del coral, entre otros (White et al., 2000; Huges et al., 2003), actividades que pueden potenciar los efectos naturales. En los últimos años, se ha dado gran importancia al papel que cumplen los factores bióticos de estrés sobre los corales, ya que afectan directa y negativamente la aptitud física (fitness) del coral (Rotjan y Lewis, 2008), afectando todo el ecosistema. Uno de estos factores bióticos es la coralivoría; proceso que consiste en el consumo directo de los pólipos coralinos por parte de depredadores, ocasionando la muerte total o parcial de la colonia coralina o restringiendo su capacidad de recuperación por del daño infligido (Baums et al., 2003).

Existen diversos grupos animales que se han especializado como coralívoros, dentro de los cuales los moluscos tienen una importante representación. En la actualidad se conocen 20 especies coralívoras de este grupo, todas pertenecientes a la clase Gasteropoda (Rotjan y Lewis, 2008) dentro de los que se encuentra Jenneria pustulata, (Lightfoot, 1786), un caracol perteneciente a la Familia Ovulidae que se puede encontrar desde el norte del Golfo de California hasta el Perú y que se alimenta de corales escleractineos (Lorenz y Feshe 2009).

En Colombia, esta especie se ha registrado en los arrecifes coralinos de Isla Gorgona y la ensenada de Utría (Navas-Camacho et al., 2010); sin embargo, no se han realizado investigaciones conducentes a conocer sus efectos sobre estos arrecifes coralinos. De esta forma, la presente investigación pretende determinar la distribución de tallas y cuantificar la tasa de coralivoría de este depredador en los arrecifes de La Azufrada y Playa Blanca del Parque Nacional Natural Gorgona.

\section{INTRODUCTION}

Coral reefs are bioconstructions (i.e. structures constructed by organisms) that provide a great variety of microhabitats to different species of fish and marine invertebrates (Cumming, 1999; Alvarez-Filip and Gil, 2006). Thus, coral reefs are among the ecosystems with the greatest biological diversity worldwide (Rotjan and Lewis, 2008), a feature that confers ecosystems high resilience (Valiente et al., 2015). Despite de above, these ecosystems are vulnerable to a guild of threats, including biotic (bioerosive effects of fishes, annelids, crustaceans, echinoderms and mollusks among others - Glynn and Enochs, 2008), and abiotic factors (e.g. temperature changes, extreme low tides and storms). In addition, coral reefs are affected by human activities, such as overfishing, water pollution and manual extraction of corals (White et al., 2000; Huges et al., 2003), which can accelerate and exacerbate the natural hazards. Recently, the role of biotic stressors on corals has been highlighted because these factors directly and negatively affect the fitness of corals (Rotjan and Lewis, 2008), thereby affecting the entire ecosystem. One of these biotic factors is corallivory: the direct consumption of coral polyps by predators. This can cause the total or partial death of the coral colony or restrict the ability of the corals to recover from the wounds inflicted (Baums et al., 2003).

Organisms from different animal groups have specialized as corallivorous, being mollusks one the most representative. Currently, 20 species of this group have been identified as corallivorous, all of them belonging to the class Gasteropoda (Rotjan and Lewis, 2008), including Jenneria pustulata (Lightfoot, 1786), a sea snail that belongs to the Ovulidae family. This snail is found from the northern Gulf of California to Peru and feeds mainly on scleractinian corals (Lorenz and Feshe 2009).

In Colombia, this species has been registered in the coral reefs of Gorgona Island and the Utria inlet (NavasCamacho et al., 2010); however, no research has been conducted to elucidate the effects of this snail on the coral reefs of these localities. Thus, the present research aims to determine the size distribution and quantify the corallivory rate of this species in La Azufrada and Playa Blanca reefs of the Gorgona Natural National Park. 


\section{ÁREA DE ESTUDIO}

La isla Gorgona $\left(2^{\circ} 58^{\prime} \mathrm{N}, 78^{\circ} 11^{\prime} \mathrm{W}\right.$; Figura 1$)$, ubicada aproximadamente a $30 \mathrm{Km}$ del continente (Guapi, Cauca), es el territorio insular más extenso $\left(13,2 \mathrm{Km}^{2}\right)$ sobre la plataforma continental del Pacífico colombiano. La isla está influenciada por el Cinturón de Convergencia Intertropical, lo que determina su clima bi-estacional (Zapata et al., 2010). La temperatura superficial del mar varía entre $26^{\circ}$ y $29^{\circ} \mathrm{C}$, pero en ocasiones puede descender a menos de $19^{\circ} \mathrm{C}$ durante eventos de surgencia hacia comienzos del año (Díaz et al., 2001; Zapata, 2001). Las principales formaciones coralinas (La Azufrada y Playa Blanca) se encuentran sobre el margen oriental de la Isla. La Azufrada (LA) mide $\sim 780 \mathrm{~m}$ de largo por $\sim 80-180 \mathrm{~m}$ de ancho y cubre cerca de $0.094 \mathrm{~km}^{2}$. Playa Blanca (PB) está constituida por dos grandes parches arrecifales separados por un canal de $\sim 60 \mathrm{~m}$ de ancho: el más pequeño, hacia el norte, tiene $\sim 240 \mathrm{~m}$ de largo por $\sim 40 \mathrm{~m}$ de ancho, mientras que el más grande, hacia el sur, tiene una longitud $\sim 930 \mathrm{~m}$ y un ancho que varía entre $\sim 60 \mathrm{~m}$ y 230 $\mathrm{m}$. En conjunto cubren un área aproximada de $0.098 \mathrm{~km}^{2}$. El principal constructor del andamio arrecifal es la especie de coral ramificado Pocillopora damicornis (familia Pocilloporidae) (Parada y Nikolaevna, 1990; Zapata, 2001; Zapata y VargasÁngel, 2003; Palacios et al., 2014)

\section{STUDY AREA}

Gorgona Island $\left(2^{\circ} 58^{\prime} \mathrm{N}, 78^{\circ} 11^{\prime} \mathrm{W}\right.$; Figure 1$)$ is located approximately $30 \mathrm{~km}$ from the mainland (Guapi, Cauca) and represents the most extensive island territory $\left(13.2 \mathrm{~km}^{2}\right)$ on the continental shelf of the Colombian Pacific coast. The island is influenced by the Intertropical Convergence Zone, which determines its bimodal climatic regime (Zapata et al., 2010). The sea surface temperature varies between $26^{\circ}$ and $29^{\circ} \mathrm{C}$, although it can occasionally descend below $19^{\circ} \mathrm{C}$ during upwelling events at the beginning of the year (Díaz et al., 2001; Zapata, 2001). The main coral reef formations (La Azufrada and Playa Blanca) are located on the eastern side of the island. La Azufrada (LA) measures $\sim 780 \mathrm{~m}$ long by $\sim 80-180 \mathrm{~m}$ wide and covers approximately $0.094 \mathrm{~km}^{2}$. Playa Blanca (PB) is composed of two large coralline patches separated by a channel $\sim 60 \mathrm{~m}$ wide: the smaller to the north is $\sim 240 \mathrm{~m}$ long by $\sim 40 \mathrm{~m}$ wide, and the largest to the south is $\sim 930 \mathrm{~m}$ long and a width that varies between $\sim 60 \mathrm{~m}$ and $230 \mathrm{~m}$. Together, these patches cover an approximate area of $0.098 \mathrm{~km}^{2}$. The main reef-building coral species is the branched coral Pocillopora damicornis (family Pocilloporidae) (Parada and Nikolaevna, 1990; Zapata, 2001; Zapata and Vargas-Ángel, 2003; Palacios et al., 2014)

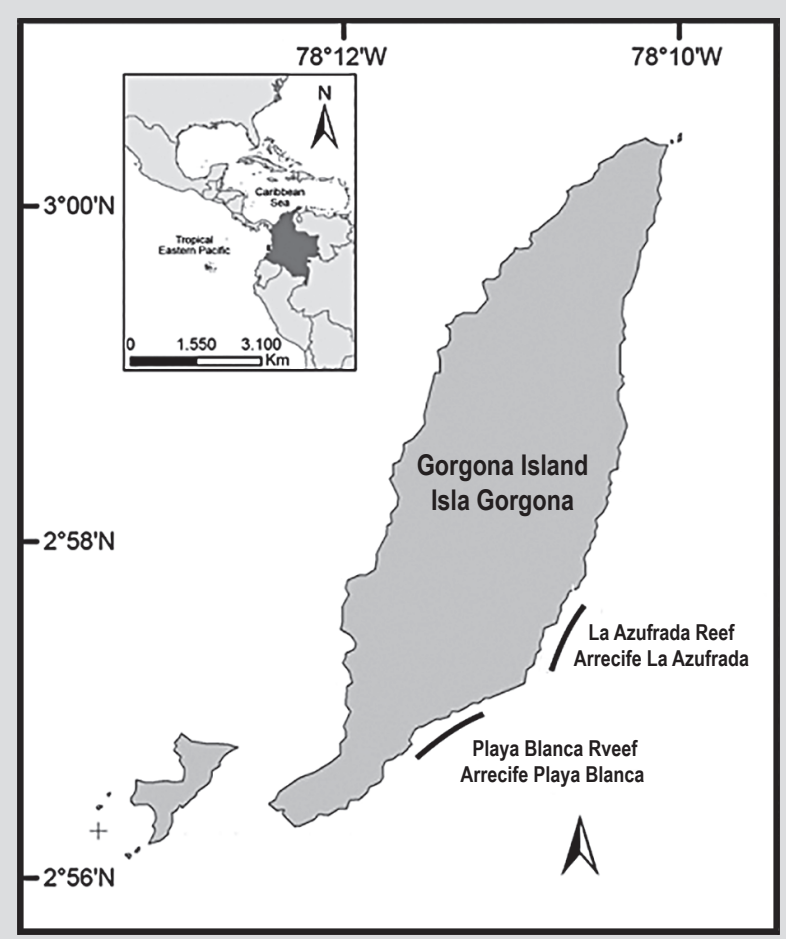

Figura 1. Mapa de la Isla Gorgona en donde se muestran los dos sitios de muestreo: los arrecifes La Azufrada y Playa Blanca.
Figure 1. Gorgona Island map showing the two sampling sites: La Azufrada and Playa Blanca reefs. 


\section{MATERIALES Y MÉTODOS}

Trabajo de campo y laboratorio

Se efectuaron dos salidas de campo: una al arrecife LA (abril de 2015) y otra al arrecife de PB (agosto de 2015). Como estos caracoles viven bajo las colonias de coral (Figura 2), se revisaron colonias sueltas de la matriz arrecifal, utilizando equipos SCUBA, en dos sesiones al día. Se colectaron y midieron (longitud de la concha en $\mathrm{mm}$ ) todos los individuos de $J$. pustulata encontrados bajo las colonias; posterior a la medición fueron liberados. Con los datos se determinó la estructura de tallas de la especie en cada arrecife. En adición, en cada arrecife se colectaron 15 individuos (y un número idéntico de fragmentos de coral) con los cuales se realizó el experimento de consumo coralino bajo condiciones controladas en los laboratorios del PNN Gorgona.

\section{MATERIALS AND METHODS}

\section{Field and laboratory work}

Field data collection was carried out during April 2015 in LA and August 2015 in PB reefs. Because $J$. pustulata normally dwells the underside of coral colonies when inactive (daytime, Figure 2), loose colonies from the reef framework were surveyed, using SCUBA diving (twice a day). All individuals were counted and measured (shell length in $\mathrm{mm}$ ) in order to determine the size structure of the species in each reef. In addition, 15 individuals from each reef (and an identical number of coral fragments) were collected and used for the coral consumption experiment performed under controlled conditions in the Gorgona NNP laboratories.

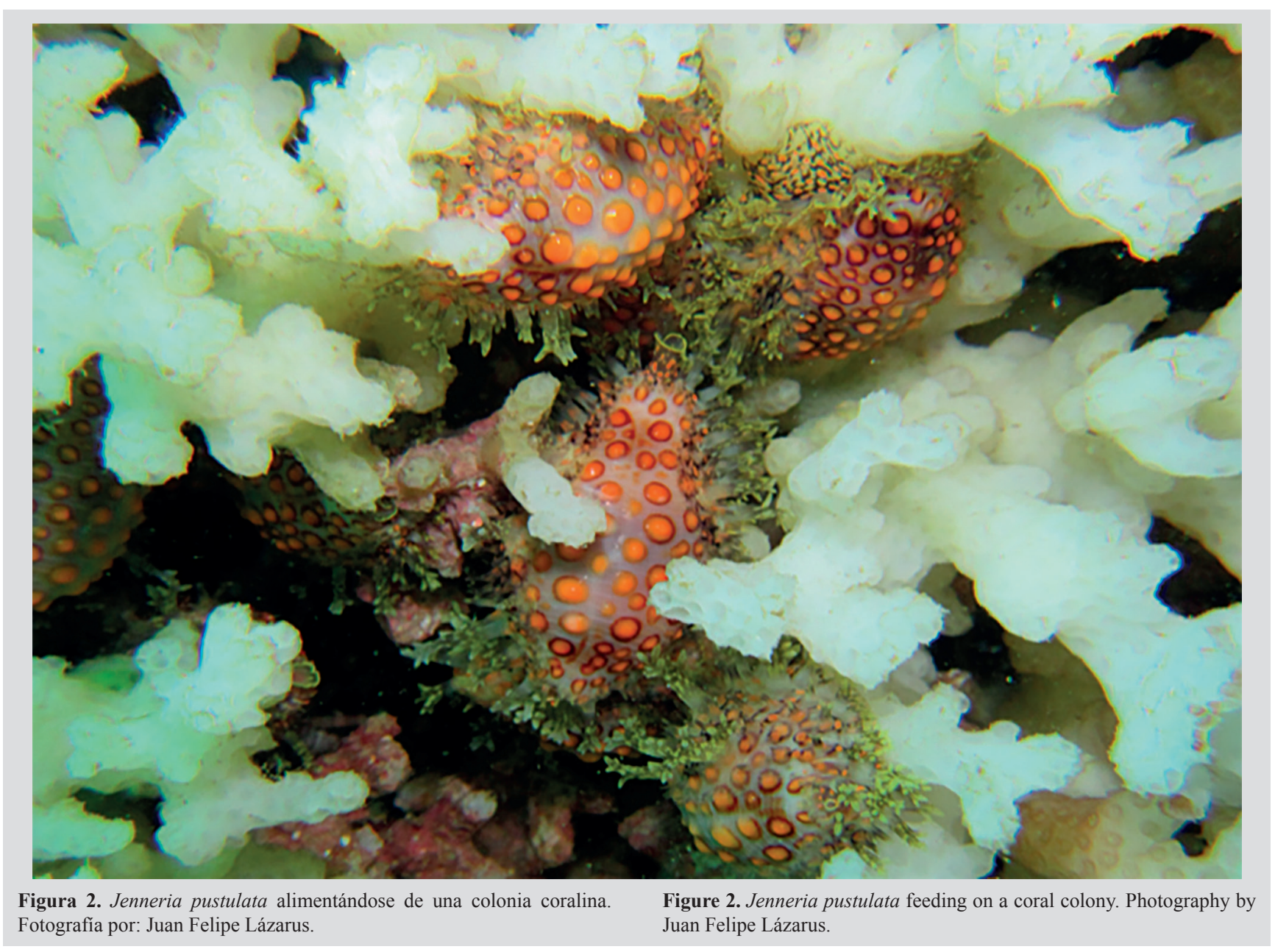

Los individuos de $J$. pustulata y los fragmentos de coral previamente colectados durante la fase de campo, fueron utilizados para realizar el experimento de coralivoría.
Each pair, composed of one specimen of $J$. pustulata and one coral fragment ( $\mathrm{n}=15$ pairs) were individually introduced into $16 \mathrm{~L}$ capacity aquaria over a 
En acuarios de $16 \mathrm{~L}$ de capacidad $(\mathrm{n}=15)$ se introdujeron de manera individual por un periodo de $24 \mathrm{~h}$, individuos de $J$. pustulata y fragmentos vivos de coral (un individuo de $J$. pustulata y un fragmento de coral por acuario; el fragmento de coral asignado a cada caracol provenía de la colonia en la cual el caracol fue capturado). Durante el desarrollo de los experimentos, los acuarios fueron vigilados y el agua fue recambiada y oxigenada (con motores de ventilación) de manera constante. Posteriormente, las lesiones resultado de la depredación por parte del caracol (Figura 3), fueron fotografiadas utilizando una cámara Canon D30. Con el software de libre distribución ImageJ 64 (Abramoff et al., 2004) se calcularon las áreas $\left(\mathrm{mm}^{2}\right)$ de las lesiones a partir de las fotografías. period of $24 \mathrm{~h}$. The coral fragment assigned to each snail was obtained from the colony where the snail was originally found and captured. During the experiment, the aquaria were continuously monitored, and water was replenished and oxygenated (with ventilation motors). The injuries caused to the fragments by the snails (Figure 3) were photographed using a Canon D30 camera. Using the free software ImageJ 64 (Abramoff et al., 2004), the area $\left(\mathrm{mm}^{2}\right)$ of the injuries was calculated from the photographs.

\section{Statistical analysis}

After confirming the assumptions of the parametric tests, snails size was compared between reefs ( 2 levels fixed) using one-way analysis of variance. The size structure for

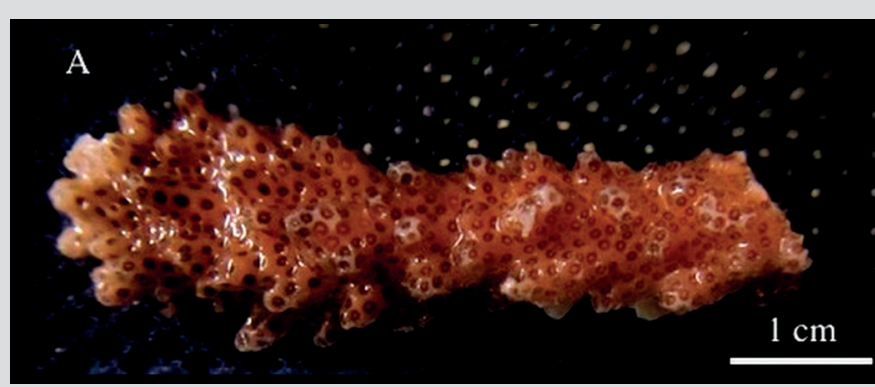

Figura 3. Fragmento de Pocillopora sp. antes (A) y después (B) de ser expuesto a coralivoría por Jenneria pustulata durante $24 \mathrm{~h}$.

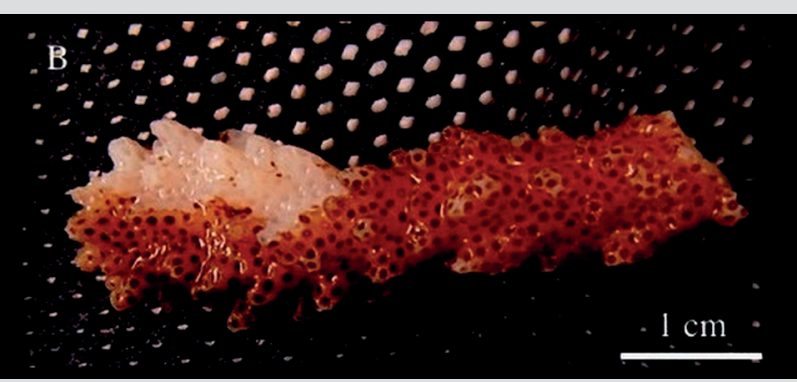

Figure 3. Pocillopora sp. fragment before (A) and after (B) corallivory by Jenneria pustulata during $24 \mathrm{~h}$.

\section{Análisis estadístico}

Después de confirmar los supuestos de las pruebas paramétricas, se evaluaron las tallas de los organismos mediante análisis de varianza simple con arrecife (2 niveles fijo) como factor explicativo. Además, se comparó la estructura de tallas de los organismos provenientes de cada arrecife con una prueba de Anderson Darling para dos muestras (Engmann et al., 2011). En adición, se realizó un análisis de varianza simple sobre los datos de consumo de tejido coralino obtenidos en cada uno de los arrecifes. Finalmente, el consumo de tejido coralino se evaluó con un análisis de covarianza, utilizando el arrecife de procedencia como variable explicativa y la talla de los caracoles como la covariable. Todos los análisis estadísticos fueron realizados utilizando el programa de libre distribución $\mathrm{R}(\mathrm{R}$ Development Core Team, 2014) y siguiendo los supuestos estadísticos de Zar (Zar, 1999). each reef was compared using an Anderson-Darling test for two samples (Engmann et al., 2011). In addition, a oneway ANOVA was used to evaluate coral tissue consumption between reefs. Finally, an ANCOVA was performed on coral tissue consumption with reef as the explanatory variable and shell size as the covariate. All the statistical analyses were carried out using the free software R (R Development Core Team, 2014) and following the statistical assumptions of Zar (Zar, 1999).

\section{RESULTS}

\section{Size and size structure}

A total of 201 individuals of $J$. pustulata were examined and measured, with 74 (36.8\%) collected from LA and $127(63.2 \%)$ from PB. The mean $( \pm \mathrm{DE})$ shell length was slightly higher for specimens from PB $(20.5 \pm 3.40 \mathrm{~mm})$ than for those from LA (19.6 $\pm 4.71 \mathrm{~mm})$ (Figure 4). Although the previous values appear similar, statistical analysis showed 


\section{RESULTADOS}

\section{Talla y estructura de tallas}

Se examinaron y midieron un total de 201 individuos de $J$. pustulata, de los cuales 74 (36.8\%) fueron colectados en LA y 127 (63.2\%) en PB. La media ( \pm DE) del largo de la concha fue ligeramente mayor en PB $(20.5 \pm 3.40$ $\mathrm{mm})$ que en LA (19.6 $\pm 4.71 \mathrm{~mm})$ (Figura 4). Aunque los anteriores valores son aparentemente similares, el análisis estadístico mostró que dicha diferencia es significativa ( $\mathrm{F}$ $(0,05(2) 1 ; 199)=11.24 ; \mathrm{P}<0.001)$. En adición, se observa que el rango de variación en los individuos de $\mathrm{PB}$ estuvo entre 16.5 y $25.0 \mathrm{~mm}$, mientras que en LA fue más amplio y osciló entre 14.0 y $24.0 \mathrm{~mm}$. differences $\left(\mathrm{F}_{(0,05(2) 1 ; 199)}=11.24 ; \mathrm{P}<0.001\right)$. In addition, $\mathrm{PB}$ snails' size ranged from 16.5 to $25.0 \mathrm{~mm}$, whereas in LA the size variation was wider and ranged from 14.0 to $24.0 \mathrm{~mm}$.

The size distribution showed that most (60.8\%) of the snails from LA ranged between 17 and $21 \mathrm{~mm}$ long; this size distribution differed from the Normal distribution $(\mathrm{A}=0.92 ; \mathrm{P}=0.019)$ (Figure $5 \mathrm{~A})$. The same analysis for the snails of PB showed that most (78.4\%) clumped between 18 and $22 \mathrm{~mm}$; this size distribution also differed significantly from the Normal distribution $(\mathrm{A}=1.44 ; \mathrm{P}<0.001)$ (Figure $5 \mathrm{~B})$. Finally, a comparison of the size structure between both reefs showed that they depicted different structures $(\mathrm{A}=5.48 ; \mathrm{P}=0.002)$.

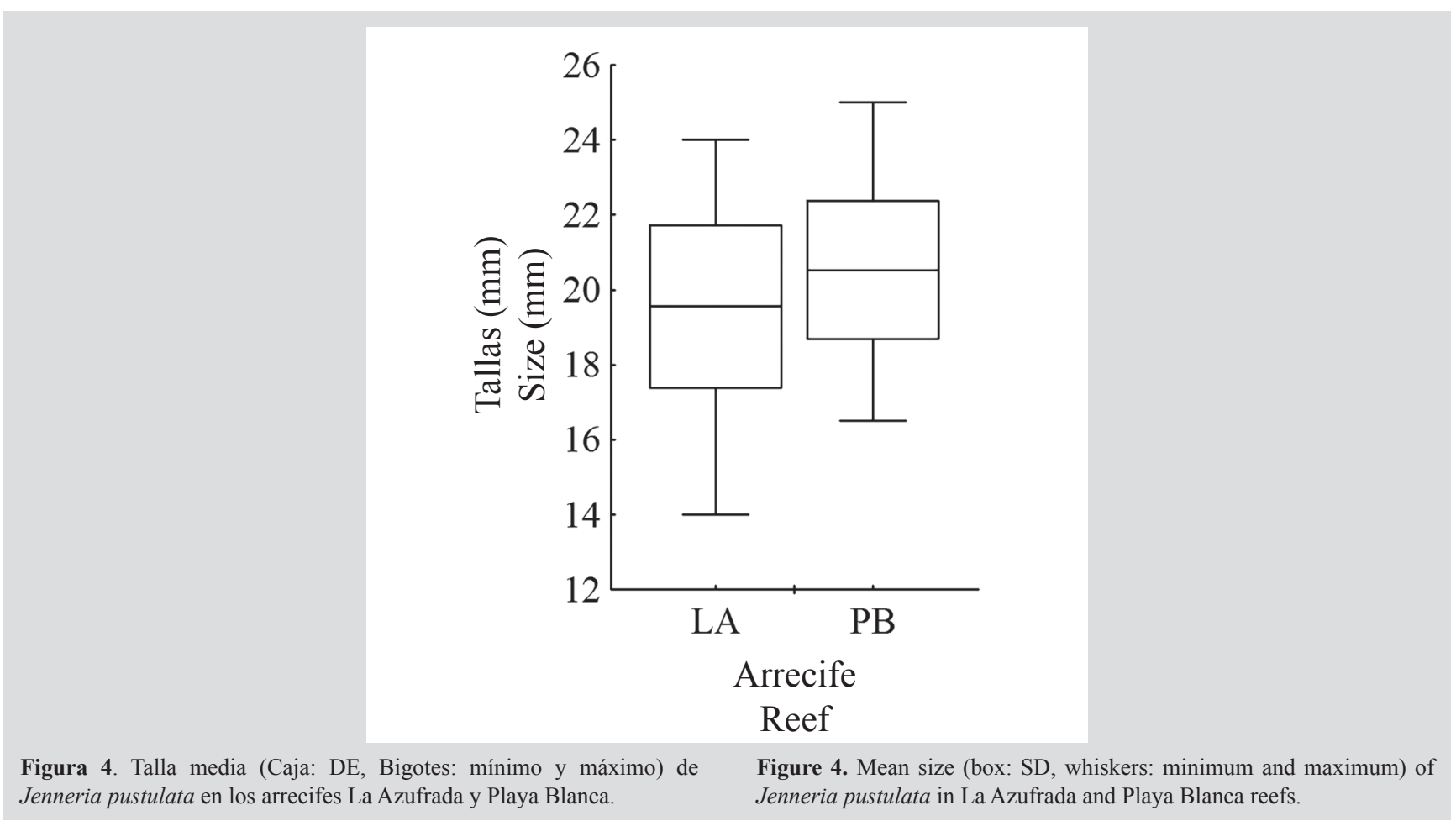

La mayoría (60.8\%) de los individuos de J. pustulata en LA se encuentran distribuidos entre 17 y $21 \mathrm{~mm}$ de largo. La distribución de tallas de estos caracoles no se ajustó a la distribución Normal ( $\mathrm{A}=0.92 ; \mathrm{P}=0.019)$ (Figura $5 \mathrm{~A})$. Por su parte, la mayoría (78.4\%) de los caracoles de $\mathrm{PB}$ se encuentran distribuidos principalmente entre 18 y $22 \mathrm{~mm}$ de largo; esta distribución de tallas también difirió significativamente de la distribución Normal $(\mathrm{A}=1.44 ; \mathrm{P}<0.001)$ (Figura 5B). Finalmente, al comparar la estructura de tallas entre ambos arrecifes, se encontró que son diferentes entre sí $(\mathrm{A}=5.48 ; \mathrm{P}=0.002)$.

\section{Consumption of coral tissue}

The corallivory experiment with LA snails had a success rate of $44.4 \%$; that is, of the initial 18 snails, only 8 consumed tissue. However, among the PB snails, $66.7 \%$ (10 of 15) consumed coral tissue. A positive relationship between snails' size and the amount of coral tissue consumed in LA $\left(\mathrm{R}^{2}=0.81\right)$ and $\mathrm{PB}\left(\mathrm{R}^{2}=0.53\right)$ was observed (Figure 6). The average consumption of coral tissue $\left(\mathrm{mm}^{2} \mathrm{day}^{-1}\right)$ per snail $\pm \mathrm{DE}$ was $105.9 \pm 77.01$ in LA and $130.5 \pm 105.50$ in PB. The consumption range varied between (31.1 - 242.2) and (21.0 - 298.0) $\mathrm{mm}^{2} \mathrm{day}^{-1}$ for LA and PB respectively. 


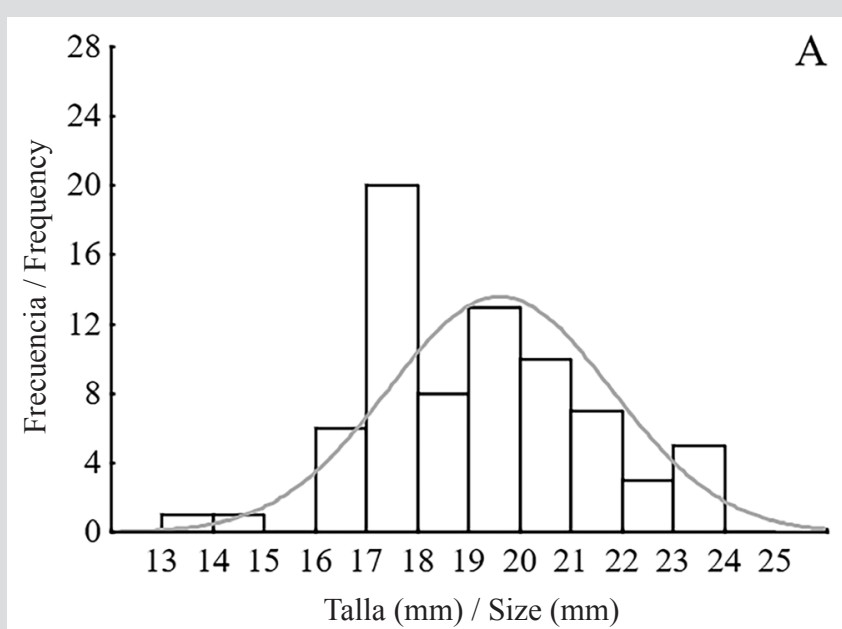

Figura 5. Distribución de tallas de Jenneria pustulata en los arrecifes La Azufrada (A) y Playa Blanca (B), isla Gorgona.

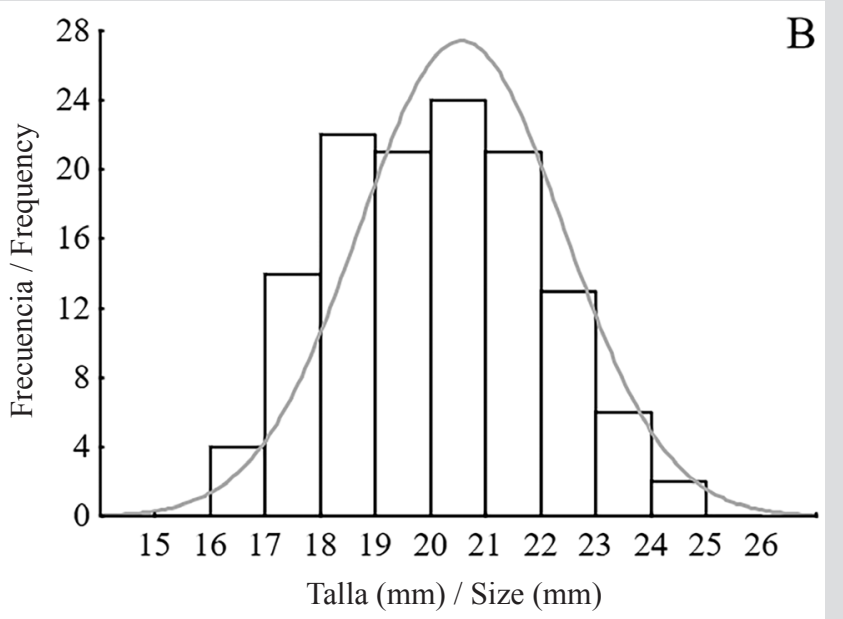

Figure 5. Size distribution of Jenneria pustulata in La Azufrada (A) and Playa Blanca (B) reefs, Gorgona Island.

\section{Consumo de tejido coralino}

El experimento de coralivoría con los caracoles de LA tuvo un porcentaje de éxito del $44.4 \%$, es decir, de los 18 caracoles iniciales, solo 8 consumieron tejido; mientras que de los caracoles provenientes de PB el 66.7\% (10 de 15) consumió tejido coralino. Es claro que existe una relación directamente proporcional entre el tamaño de los caracoles y la cantidad de tejido coralino consumido tanto en LA $\left(\mathrm{R}^{2}=0.81\right)$ como en $\mathrm{PB}\left(\mathrm{R}^{2}=0.53\right)$ (Figura 6). El consumo medio por caracol $\pm \mathrm{DE}$ de tejido coralino, en $\mathrm{mm}^{2} \mathrm{día}^{-1}$, fue de $105.9 \pm 77.01$ en LA y $130.5 \pm 105.50$ en PB. El rango de consumo osciló entre (31.1 - 242.2) y (21.0 - 298.0) $\mathrm{mm}^{2} \mathrm{dí}^{-1}$ en LA y $\mathrm{PB}$ respectivamente.

Aunque el consumo medio de tejido coralino, sin considerar la talla de los caracoles es superior en PB que en LA (130.5 vs. 105.9), el ANCOVA mostró que hay un efecto muy significativo del tamaño de los caracoles (P), lo cual muestra que un caracol de un tamaño dado, consumirá más tejido coralino en LA que en PB (Figuras 6 y 7).

\section{DISCUSIÓN}

Los arrecifes coralinos ubicados en el costado oriental de la isla Gorgona presentan un alto grado de similitud, tanto en tamaño como en estructura y en su marcada dominancia por corales del género Pocillopora (Prahl, 1986; Palacios et al., 2014). En adición, son espacialmente cercanos, por lo que se podría inferir que existe un alto grado de comunicación. Sin embargo, en el presente estudio se encontraron 1.7 veces más individuos
Without considering the size of the snails, the average consumption of coral tissue was higher in PB than in LA (130.5 vs. 105.9); however, the ANCOVA showed that snail size has a very significant effect $(\mathrm{P})$, with a snail of a given size consuming more coral tissue in LA than in PB (Figures 6 and 7).

\section{DISCUSSION}

The coral reefs located on the eastern side of Gorgona Island show a high degree of similarity, both in their size and structure as well as in the dominance of the genus Pocillopora (Prahl, 1986; Palacios et al., 2014). In addition, these reefs are geographically close; thus, a high degree of communication could be inferred. However, in the present study, the number of $J$. pustulata individuals was 1.7-times greater in PB than in LA despite the similar sampling effort in the two reefs ( $24 \mathrm{~h}$ in each reef). While the two reefs are very similar, the amount of sediment they receive by runoff varies significantly and is higher in $\mathrm{PB}$ $\left(293 \mathrm{~g} / \mathrm{m}^{2}\right.$ day $\left.^{-1}\right)$ than in LA (95 g/ $\mathrm{m}^{2}$ day $\left.^{-1}\right)$ (Blanco, 2009). Sediment load entering the reef has an important effect on the reefhealth and could eventually increase its vulnerability to disease and reduce the ability of the coral to compete for space with other organisms (e.g., algae) (Granja and López, 2008; Erftenmeijer et al., 2012). Observations in the field suggest that $J$. pustulata has a marked preference for colonies with some degree of deterioration, which may be related to the ability of the snail to mimic this type of colony, thereby avoiding predation by fish, such as 


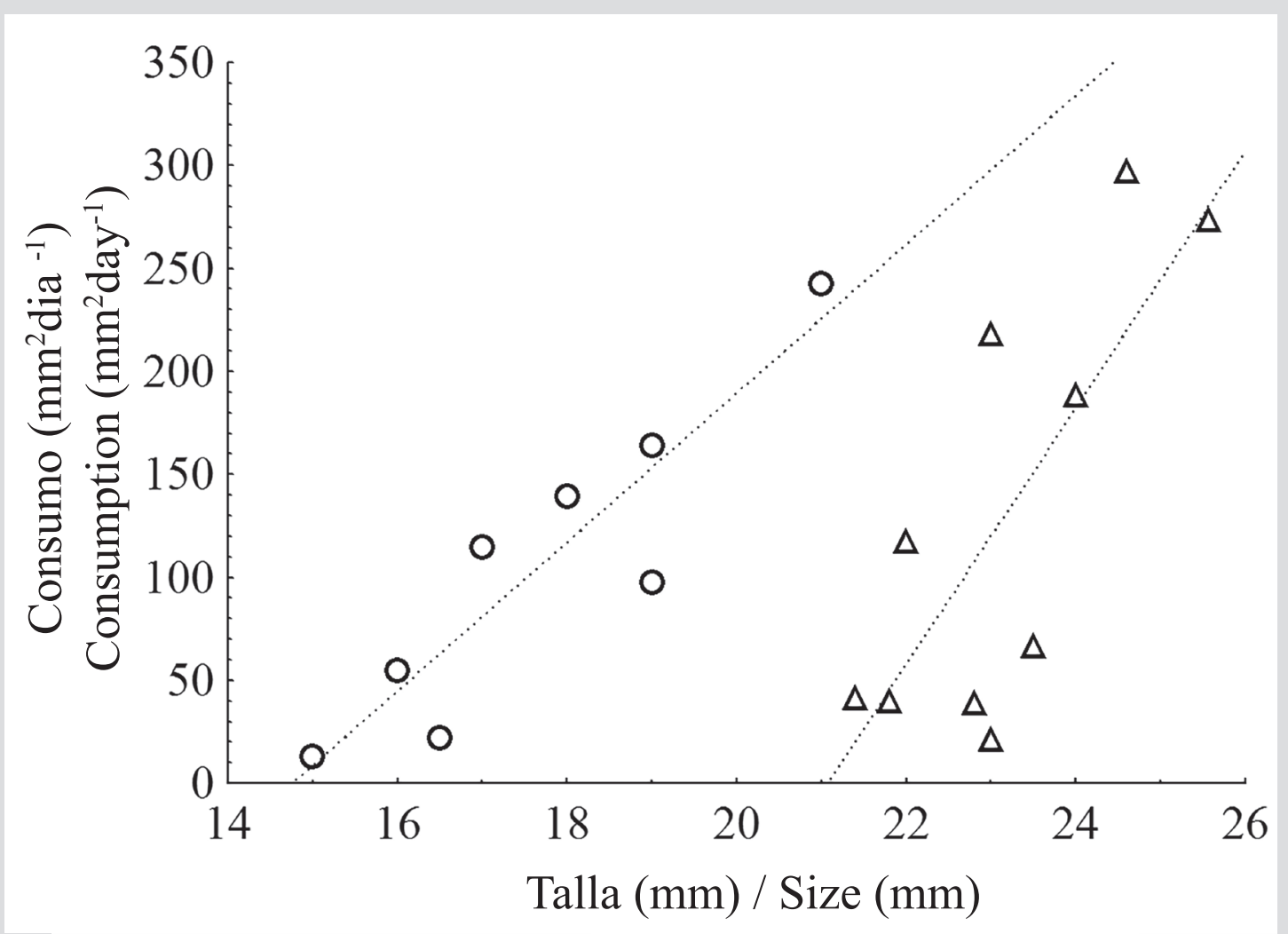

Figura 6. Relación entre el tamaño (longitud de la concha, en mm) y el tejido coralino consumido $\left(\mathrm{mm}^{2}\right)$ por día por Jenneria pustulata en los arrecifes La Azufrada ( $\mathrm{P}=0.002$; círculos) y Playa Blanca $(\mathrm{P}=0.01$; triángulos $)$.
Figure 6. Relation between size (shell length in $\mathrm{mm}$ ) and coral tissue consumed $\left(\mathrm{mm}^{2}\right)$ per day by Jenneria pustulata in La Azufrada $(\mathrm{P}=0.002$; circles) and Playa Blanca ( $\mathrm{P}=0.01$; triangles) reefs.

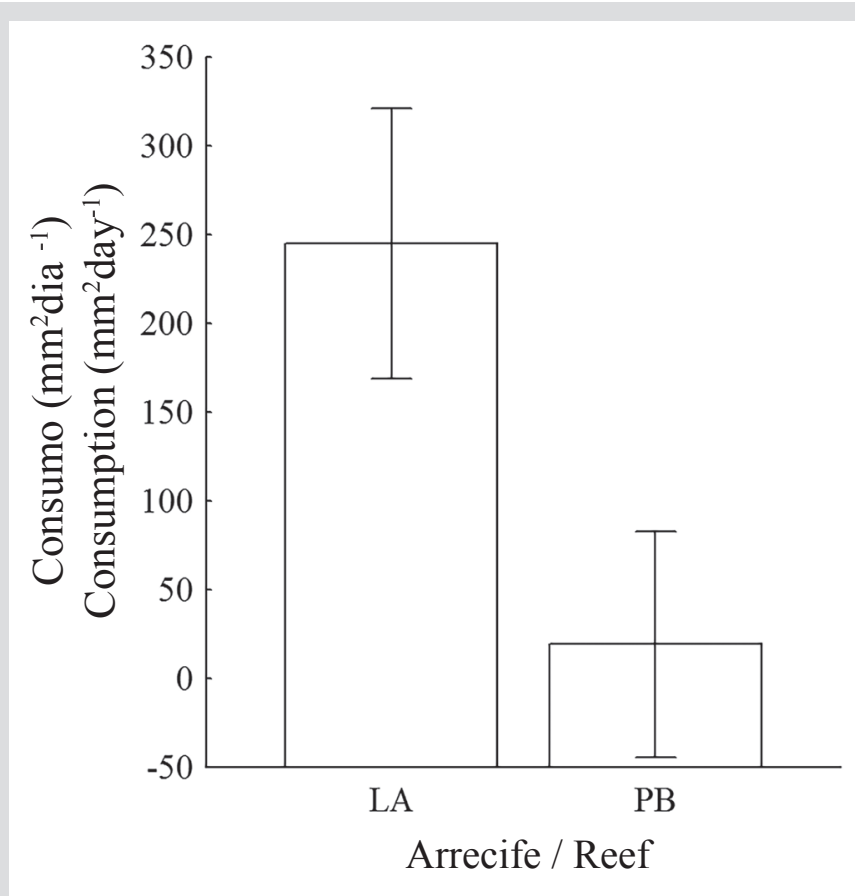

Figura 7. Tejido $\left(\mathrm{mm}^{2} \mathrm{dí}^{-1}\right)$ de Pocillopora sp. consumido por Jenneria pustulata en los arrecifes La Azufrada y Playa Blanca.
Figure 7. Pocillopora sp. tissue consumed $\left(\mathrm{mm}^{2} \mathrm{day}^{-1}\right)$ by Jenneria pustulata in La Azufrada and Playa Blanca reefs. 
de $J$. pustulata en PB que en LA, aunque el esfuerzo de muestreo (ca. $24 \mathrm{~h}$ en cada arrecife) fue similar en los dos arrecifes. Si bien, como se mencionó, los dos arrecifes son muy similares, la cantidad de sedimento que reciben por escorrentía varía significativamente entre los dos, siendo mayor en PB (293 g/ $/ \mathrm{m}^{2}$ día $\left.{ }^{-1}\right)$ que en LA $\left(95 \mathrm{~g} / \mathrm{m}^{2}\right.$ día 1) (Blanco, 2009). La cantidad de sedimentos que entran al arrecife tienen un efecto importante en la salud del mismo y podrían, eventualmente, hacerlo más vulnerable a enfermedades y reducir la capacidad del coral para competir por el espacio con otros organismos (e.g algas) (Granja y López, 2008; Erftenmeijer et al., 2012). Observaciones en campo, sugieren que $J$. pustulata tiene una marcada preferencia por colonias con algún grado de deterioro; es posible que esta preferencia se relacione con la capacidad del caracol de mimetizarse con este tipo de colonias, de tal forma que evite, de alguna manera, la depredación por peces como Arothron meleagris, Sufflamen verres y Pseudobalistes naufragium (Guzman 1988; Glynn, 2004). Por otro lado, el mayor número de individuos de J. pustulata encontrado en el arrecife de PB muestran una mayor tasa de depredación por parte del caracol en este arrecife al compararlo con el arrecife de LA; por lo tanto es factible plausible pensar que la sinergia de los efectos resultantes del influjo de sedimentos proveniente de las quebradas al interior de la isla, el consumo de tejido coralino por parte de $J$. pustulata y la subsecuente colonización del sustrato libre resultado de esta actividad por parte de las algas podrían afectar de forma significativa el estado de salud del arrecife de PB. Sin embargo, para corroborar estas afirmaciones, se necesitan más investigaciones que ahonden en el estado fisiológico de los corales en el arrecife de $\mathrm{PB}$, pues según Tiliyanov y Tiliyanova (2005), la capacidad de recuperarse de una lesión en el tejido vivo depende de varios factores, entre ellos el tipo de lesión sufrida, el tipo de crecimiento (ramificada, masiva o sub-masiva) y el estado fisiológico en el que se encuentre la colonia.

\section{Talla y estructura de tallas}

La talla de los gasterópodos es una característica que puede verse afectada por factores internos como el estado de desarrollo del animal y la edad; y por factores externos como las condiciones ambientales (Wilbur y Owen, 1964). Según Bashevkin y Pechenik (2015) la temperatura tiene un efecto importante sobre el crecimiento de los moluscos, con temperaturas más altas ocasionando tasas de crecimiento más aceleradas que temperaturas bajas. Vale la pena mencionar que
Arothron meleagris, Sufflamen verres and Pseudobalistes naufragium (Guzman 1988; Glynn, 2004). The greater number of individuals of $J$. pustulata found in the PB reef means a higher predation rate by the snail in this reef when compared to the LA reef; therefore, the synergy of the effects resulting from the influx of sediment carried from the rivers on the island, the consumption of coral tissue by $J$. pustulata and the subsequent colonization of the available substrate by algae, could significantly affect the health status of the PB reef. However, to corroborate these statements, additional research into the physiological state of the corals in the PB reef is required; because according to Tiliyanov and Tiliyanova (2005), the coral ability to recover from an injury on the living tissue depends on several factors, including the type of injury suffered, the growth form (branched, massive or submassive) and the current physiological state of the colony.

\section{Size and size structure}

The length of a gastropod is a characteristic that can be affected by internal factors, such as the animal's stage of development and age, and by external factors, such as environmental conditions (Wilbur and Owen, 1964). According to Bashevkin and Pechenik (2015), temperature has an important effect on the growth of mollusks, with high temperatures leading to faster growth rates than low temperatures. The reefs were visited during two different seasons: LA was visited during April 2015, while PB was visited during August of the same year, and these two seasons have contrasting climatic conditions. Between January and April, the waters cool due to upwelling in the central part of the Gulf of Panama that generates a cold front from the north and influences the waters of the Colombian Tropical Eastern Pacific, whereas from May to December, the water temperatures are higher (Giraldo et al., 2008). Seasonality may have been partly responsible for the observed differences in shell length (larger snails on average in August in PB [warm waters] and smaller in April in LA [cold waters]) between the snails in both reefs; however, this hypothesis should be tested via simultaneous sampling. Moreover, it has been shown that there is a directly proportional relationship between sample size and population density (Connor et al., 2000), which could also be interpreted as samples with higher abundances could sample a wider range of population characteristics. In PB, more individuals were 
los arrecifes fueron visitados durante dos épocas diferentes: LA se visitó durante abril de 2015, mientras que PB se visitó durante agosto del mismo año. Las dos épocas presentan condiciones climáticas contrastantes, entre enero y abril hay enfriamiento de las aguas debido a un proceso de surgencia en la parte central del Golfo de Panamá que genera una lengua fría proveniente del norte con influencia sobre las aguas de Pacífico Tropical Oriental colombiano, mientras que durante mayo y diciembre, las temperaturas del agua son superiores (Giraldo et al., 2008). Es posible que esto haya ocasionado en parte las diferencias observadas en términos de largo de la concha (caracoles más grandes en promedio en agosto en PB [aguas cálidas] y más pequeños en abril en LA [aguas frías]) entre los caracoles en los dos arrecifes; sin embargo, es muy deseable probar esta hipótesis haciendo muestreos simultáneos. Por otro lado, existe una relación directamente proporcional entre el tamaño muestral y la densidad poblacional (Connor et al., 2000), lo cual también podría entenderse como que muestras con mayores abundancias podrían capturar un ámbito más amplio de características poblacionales. En PB se capturaron más individuos que en LA por lo cual se esperaría que se obtuvieran individuos en un rango de tamaños más amplio, lo que se vería reflejado en tamaños promedios mayores en dicho arrecife.

Finalmente, en LA existe evidencia de liberación de gases sulfurosos, aunque es una probabilidad muy baja, estos gases podrían estar disminuyendo el $\mathrm{pH}$ en las aguas circundantes, con el concomitante efecto sobre calcificación en las conchas y por lo tanto el registro de tamaños promedios inferiores.

\section{Consumo de tejido coralino}

El papel ecológico de los coralívoros ha sido catalogado por algunos autores como el de modelar y estructurar las poblaciones y las dinámicas de la presa; este papel puede verse afectado por factores como la abundancia relativa de la presa y la talla y densidad del depredador en el arrecife (Bruckner et al., 1997). Jenneria pustulata es un depredador con un alto grado de especificidad, que se alimenta casi siempre de corales escleractinios con una marcada preferencia por el género Pocillopora (Bertsch, 1984; Glynn, 2004; Figura 2). Considerando que los dos arrecifes son relativamente similares tanto en composición de especies como en extensión total, se esperaría que los caracoles provenientes de estos, no presentaran variaciones significativas en la cantidad de coral consumido en los experimentos. Sin embargo, según los resultados del ANCOVA, caracoles comparables en tamaño consumirían en promedio más tejido coralino en LA que en PB; como los caracoles en LA son en promedio más pequeños, es posible captured than in LA; therefore, the size range of $\mathrm{PB}$ individuals would likely be broader, which would be reflected in the larger average sizes from this reef.

\section{Consumption of coral tissue}

The ecological role of corallivores has been considered by some authors as a driver of the structural dynamics of prey populations, although this role can be affected by various factors, such as the relative abundance of the prey and the size and density of the predator in the reef (Bruckner et al., 1997). Jenneria pustulata is a highly specialized predator, almost exclusively feeds on scleractinian corals and shows a marked preference for the genus Pocillopora (Bertsch, 1984; Glynn, 2004; Figure 2). Considering that the two reefs are relatively similar in species composition and total size, the snails from each of these reefs were not expected to present significant variations in the amount of coral consumed in the experiments. However, according to the results of the ANCOVA, snails that were comparable in size would consume on average more coral tissue from LA than from PB. Since the snails from LA are on average smaller, they may be fulfilling the same function at LA as the large snails at PB in terms of coral consumption. Although this represents one possible explanation, whether interference competition occurs in this species should be investigated to help explain why the smaller snails from LA have the same consumption rate as the larger snails from PB. Studies on other corallivores, such as Coralliophila erosa, Drupella cornus and D. rugosa (Bruckner et al., 1997; Miller, 2001; Cumming 2009), show higher rates than those found for $J$. pustulata in the Gorgona reefs (Table 1). This could indicate that although this species is larger on average than C. erosa (Del Mónaco et al., 2008) and of similar size to Drupella $\mathrm{sp}$, it has a less significant effect on the coral ecosystem relative to the previously mentioned species. In addition, the $J$. pustulata radula has two pairs of lateral teeth with a rectangular base and strong hook-shaped rigid cusps (Simone, 2004), and this provision may allow it to feed without causing permanent damage to the corallites, thus allowing for more rapid and less energetically costly coral recovery.

Studies focused on the ability of branched corals of the genus Pocillopora to recover from tissue injuries (where the calcareous skeleton is not damaged) show 
que estos estén cumpliendo la misma función, en términos de consumo coralino, que caracoles grandes en PB. Aunque esta es una posible explicación a lo observado, es necesario evaluar la existencia de competencia por interferencia en esta especie, lo cual podría ayudar a establecer el hecho de que caracoles en promedio más pequeños en LA tengan el mismo consumo que caracoles más grandes en PB. Por otro lado, estudios realizados sobre otros coralívoros como Coralliophila erosa, Drupella cornus y D. rugosa (Bruckner et al., 1997; Miller, 2001; Cumming 2009) arrojan tasas más altas que las encontradas para $J$. pustulata en los arrecifes de Gorgona (Tabla 1). Esto podría indicar que aunque esta especie, en promedio es más grande que C. erosa (Del Mónaco et al., 2008) y de tamaño similar a las especies del género Drupela, causa un efecto sobre el ecosistema coralino que podría considerarse poco significativo con relación a las especies anteriormente nombradas. En adición, es importante recalcar que la rádula de $J$. pustulata presenta dos pares de dientes laterales con una base rectangular y cúspides fuertes y rígidas en forma de gancho (Simone, 2004). Es posible que esta disposición le permita alimentarse sin ocasionar daños permanentes a la coralita, permitiendo que la recuperación por parte del coral sea más rápida y energéticamente menos costosa.

Tabla 1. Tamaño de la concha $(\mathrm{mm})$ y tejido coralino consumido $\left(\mathrm{mm}^{2}\right.$. día $\left.{ }^{-1}\right)$ por diferentes especies de moluscos. $\left(\mathbf{m m}^{2} \cdot \mathbf{n}^{-1}\right)$ : Registrado durante $12 \mathrm{~h}$. * Medida en $\mathrm{cm}$.

\begin{tabular}{|c|c|c|c|c|}
\hline Especie / Species & Locación / Location & $\begin{array}{l}\text { Largo de la concha } \\
\text { / Shell length }\end{array}$ & $\begin{array}{l}\text { Tejido consumido / } \\
\text { Consumed tissue }\end{array}$ & Referencia / Reference \\
\hline \multirow[b]{2}{*}{ Coralliophila erosa (Röding 1798) } & Puerto Rico: Las Lajas, La Parguera & $17.0-19.1$ & 650 & Bruckner et al. 1997 \\
\hline & $\begin{array}{l}\text { Estados Unidos / United States } \\
\text { Florida, Florida Keys }\end{array}$ & - & 337 & Miller 2001 \\
\hline Drupella rugosa (Born 1778) & Australia: Isla Lagarto (Lizard Island). & $24-29$ & $151(\mathrm{~mm} 2 . n-1)$ & Cumming 2009 \\
\hline Drupella cornus (Röding 1978) & Australia: Isla Lagarto (Lizard Island). & $28-25$ & $181(\mathrm{~mm} 2 . \mathrm{n}-1)$ & Cumming 2009 \\
\hline \multirow{2}{*}{ Jenneria pustulata (Lightfoot, 1786) } & $\begin{array}{l}\text { Bahía de Los Ángeles: Estados Unidos } \\
\text { / Bay of Los Angeles: United States }\end{array}$ & $* 1.7$ & - & Paz García et al. 2012 \\
\hline & $\begin{array}{l}\text { Colombia: Isla Gorgona / Gorgona } \\
\text { Island }\end{array}$ & $16.5-24.0$ & 118.17 & $\begin{array}{l}\text { El presente estudio / } \\
\text { Present study }\end{array}$ \\
\hline
\end{tabular}

Estudios enfocados en la capacidad que tienen los corales ramificados del género Pocillopora para recuperarse de una lesión a nivel tisular (en donde no se daña el esqueleto calcáreo) demuestran que, aunque este proceso es energéticamente menos costoso, estas heridas tienden a ser colonizados por algas 4 o 5 días después de la aparición de la lesión en el tejido, y, aunque después de un tiempo el coral tiende a recuperarse casi completamente de la herida, esta recuperación implica un gasto energético importante, pues el coral no solo debe generar nuevos pólipos para cubrir de nuevo la zona lesionada sino que también debe regenerar los pólipos que han sido parcialmente dañados por el coralívoro that although this process is energetically less expensive than recovering from a lesson in the calcareous skeleton, these wounds tend to be colonized by algae 4 or 5 days after the injury appears in the tissue. Moreover, although the coral tends to recover almost completely from these wounds, this recovery involves a significant energy expenditure since the coral must not only generate new polyps to cover the injured area again but also regenerate the polyps that have been partially damaged by the corallivore (Titliyanov et al., 2005; TraylorKnowles, 2016). Therefore, although the damage caused by the feeding of $J$. pustulata is less than that of other corallivorous mollusks, this species may have a strong effect on the condition of the coral due to the important energy investment required for the corals to recover from the damage and to prevent the concomitant colonization of the calcareous skeleton by algae. These complications support the need for additional research to broaden our knowledge about the structure and population dynamics of this snail and corroborate the significance of its effects on the coral reefs of the Gorgona National Park.

Table 1. Shell lengths $(\mathrm{mm})$ and coral tissue consumed $\left(\mathrm{mm}^{2}\right.$.day $\left.{ }^{-1}\right)$ for different mollusk species $\left(\mathbf{m m}^{2} \cdot \mathbf{n}^{-1}\right)$ : Recorded over 12 h. * Measured in $\mathrm{cm}$.

\section{ACKNOWLEDGEMENTS}

The authors thank Universidad del Valle for funding this research, which was carried out under the Internal Research Project (C.I 7970). We also thank the Unidad de Parques Nacionales Naturales (National Park Unit) and especially the Gorgona PNN staff (X. Zorrilla and L. Payán) for their help in the logistics and organization of the field phase of this project. Thanks are also extended to Juan Felipe Lázarus, Jaime R. Cantera, Óscar Murillo, José Tavera, Andrés Carmona, Wilmar Torres, Fernando Zapata 
(Titliyanov et al. 2005; Traylor-Knowles, 2016). Esto podría significar que, aunque el daño causado por la alimentación de $J$. pustulata es menor que el de otros moluscos coralívoros, esta especie puede estar afectando fuertemente la condición del coral debido a la importante inversión energética que ellos deben hacer, no solo para recuperarse del daño recibido sino también para sobrellevar la concomitante colonización del esqueleto calcáreo por parte de las algas. Es debido a esto que es necesario realizar más investigaciones con el propósito de ampliar el conocimiento sobre la estructura y dinámica poblacional de este caracol y corroborar la significancia de sus efectos sobre los arrecifes coralinos del PNN Gorgona.

\section{AGRADECIMIENTOS}

Los autores agradecen a la Universidad del Valle por la financiación de esta investigación, realizada bajo el proyecto de Convocatoria Interna (C.I 7970). De igual manera, se agradece a la Unidad de Parques Nacionales Naturales y especialmente a los funcionarios del PNN Gorgona (X. Zorrilla y L. Payán) por su ayuda en la logística y organización de la fase de campo de este proyecto; se agradece también a Juan Felipe Lázarus, Jaime R. Cantera, Óscar Murillo, José Tavera, Andrés Carmona, Wilmar Torres, Fernando Zapata y Laksmy Gallego por el apoyo brindado durante las diferentes fases del proyecto. Finalmente, se agradece a los integrantes del Grupo de Investigación en Ecosistemas Rocosos Intermareales y Submareales Someros - LITHOS. and Laksmy Gallego for their support during the different phases of the project. Finally, we would like to thank the members of the Research Group on Intertidal and Shallow Subtidal Rocky Ecosystems - LITHOS.

\section{BIBLIOGRAFÍA / LITERATURE CITED}

Alvarez-Filip L. and I. Gil. 2006. Effects of hurricanes Emily and Wilma on coral reefs in Cozumel, Mexico. Coral Reefs, 25: 583-583.

Abramoff, M.D., P.J. Magalhaes and S.J. Ram. 2004. Image Processing with ImageJ. Biophotonics Internat., 11:36-42.

Baums, I., M. Miller and A. Szmant. 2003. Ecology of a corallivorous gastropod Coralliophila abbreviata, on two scleractinian hosts. II. Feeding, respiration and growth. Marine Biology, 142:1093-1101.

Bashevkin, S. and J. Pechenik. 2015. The interactive influence of temperature and salinity on larval and juvenile growth in the gastropod Crepidula fornicata (L.). J. Exp. Mar. Biol. Ecol., 470:78-91.

Bertsch, H. 1984. Jenneria pustulata, the pustulate cowrie. Opisthobranch, 16:9-10.

Blanco, J. 2009. Características físico-químicas de las quebradas del Parque Nacional Natural Gorgona, Pacífico Colombiano. Actual. Biol., 32:123-140.

Bruckner, R.J., A.W. Bruckner and E.H. Williams. 1997. Life history strategies of Coralliophila abbreviata Lamarck (Gasteropoda, Coralliophilidae) on the Southwest coast of Puerto Rico. Proc. 8th Int. Coral Reef Sym., 1: 627-632.

Connor, E., A. Courtney and A. Yoder. 2000. Individuals-Area relationship: The relationship between animal population density and area. Ecology, 3: 734-748. Cumming, R. 1999. Predation on reef-building corals: multiscale variation in the density of three corallivorous gastropods, Drupella spp. Coral Reefs, $18: 147-157$. Cumming, R. 2009. Case study: Impact of Drupella spp. on reef building corals of the Great Barrier Reef. Great Barrier Reef Marine Park Authority. Australia. $51 \mathrm{p}$.

Del Mónaco, C., E. Villamizar y S. Narcizo, S. 2008. Tasa de depredación Coralliophila abbreviata (Neogastropoda: Coralliophilidae) sobre algunas especies coralinas del Parque Nacional Morrocoy, Venezuela. Rev. Biol. Trop., 56:235-246.

Díaz, J., J. Pinzón, A. Perdomo, L. Barrios y M. López-Victoria. 2001. Generalidades. 17-26. En: López-Victoria M. y L.M. Barrios (Eds.). Gorgona marina: contribución al conocimiento de una isla única. INVEMAR, Santa Marta. 160 p.

Engmann, S. and D. Cousineau. 2011. Comparing distributions: The Two-Sample Anderson-Darling test as an alternate to the Kolmogorov-Smirnoff test. Journal of Applied Quantitative Methods, 6:1-17 
Erftemeijer, P.L.A., B. Riegl, B.W. Hoeksema and P.A. Todd. 2012. Environmental impacts of dredging and other sediment disturbances on corals: A review. Marine Pollution Bulletin, 64:1737-1765.

Giraldo, A., E. Rodríguez y F. Zapata. 2008. Condiciones oceanográficas en Isla Gorgona, Pacífico oriental tropical de Colombia. Lat. Am. J. Aquat. Res., $36: 121-128$

Glynn, P. 2004. High complexity food webs in low diversity Eastern Pacific Reef-Coral Communities. Ecosystems, 7:358-367.

Glynn, P., H. v. Prahl and F. Guhl. 1982. Coral reefs of Gorgona Island, with special reference to corallivores and their influence on community structure and reef development. An. Inst. Inv. Mar. Punta de Betín, 12:185-214.

Glynn, P. and C. Enochs. 2011. Invertebrates and their roles in coral reefs ecosystems. 273-325 in: Dubynsky, Z and N. Stambler. (Eds.). Coral reefs: An ecosystem in transition. Springer Science, New York. 540 p.

Granja, M. y R. López. 2008. Sedimentación en comunidades arrecifales de Huatulco, Oxaca, México. Rev. Biol. Trop., 56:1179-1187.

Guzmán, H. 1988. Distribución y abundancia de los organismos coralívoros de los arrecifes coralinos de la Isla del Caño, Costa Rica. Revista Biología Tropical, 36: 191-207.

Hughes, T.P., A.H. Baird, D.R. Bellwood, M. Card, S.R. Connolly, C. Folke, R. Grosberg, O. Hoegh-Guldberg, J.B.C. Jackson, J. Kleypas, J.M. Lough, P. Marshall, M. Nyström, S.R. Palumbi, J.M. Pandolfi, B. Rosen and J. Roughgarden. 2003. Climate change, human impacts, and the resilience of coral reefs. Science, 301:929-933.

Lorenz, F. and D. Feshe. 2009. The living Ovuliidae: a manual of the families of allied: Ovulidae, Pediculariidae and Eocypraeidae. ConchBooks, Hackenheinm, Germany. 651 p.

Miller, M. 2001. Corallivorous snail removal: evaluation of impact on Acropora palmata. Coral Reefs, 19:293-295.

Navas-Camacho, R., A. Rodríguez-Ramírez and M. Reyes-Nivia. 2010. Agents of coral mortality on reef formations of the Colombian Pacific. Rev. Biol. Trop., 58:133-138.

Palacios, M., C. Muñoz and F. Zapata. 2014. Fish corallivory on a pocilloporid reef and experimental coral responses to predation. Coral Reefs, $33: 625$ - 636. Parada, C. y N. Nikolaevna. 1990. Foraminíferos y sedimendos de Playa Blanca, Isla Gorgona.Geol. Col., 17:227-327.

Paz-García, D., A. Aldana-Moreno, R. Cabral-Tena and E. Balart. 2012. High predation by the corallivore sea snail Jenneria pustulata in a high-latitude reef in the Gulf of California. Mar. Bio. Rec., 5: 1-2.

Prahl, H. 1986. Corales y arrecifes coralinos. Isla de Gorgona. Biblioteca Banco Popular, Bogotá. 252 p.

R Development Core Team. 2014. R: A language and environment for statistical computing. http://www.Rproject.org. 07/07/2014.

Rotjan, R. and S. Lewis. 2008. Impact of coral predators on tropical reefs. Mar. Ecol. Prog. Ser., 367: 73-91.

Sánchez, J., P. Fuentes-Pardo, Í. Ní Almhain, E. Ardila-Espitia, J. Cantera-Kintz and M. Forero-Shelton. 2016. The masquerade game: marine mimicry adaptation between egg-cowries and octocorals. PeerJ 4:e2051 https://doi.org/10.7717/peerj.2051

Simone, L. 2004. Morphology and Phylogeny of the Cypraeoidea (Mollusca, Caenogastropoda). Papel Virtual Editora, Río de Janeiro. 186 p.

Starrett, A. 1993. Adaptative resemblance: A unifying concept for mimicry and crypsis. Biol. J. Lin. Soc., 48: 299-317.

Titlyanov, E. and T. Titlyanova. 2009. The Dynamics of the Restoration of Mechanical Damage to Colonies of the Scleractinian Coral Porites lutea under Conditions of Competition with Algal Settlers for Substratum. Rus. J. Mar. Biol., 3: 230-235.

Titlyanov, E., T. Titlyanova, M. Yakovleva, Y. Nakano and R. Bhagooli. 2005. Regeneration of artificial injuries on scleractinian corals and coral/algal competition for newly formed substrate. J. Exp. Mar. Bio. Ecol., 323: 27-42.

Traylor-Knowles, N. 2016. Distinctive wound-healing characteristics in the corals Pocillopora damicornis and Acropora hyacinthus found in two different temperature regimes. Mar. Biol., 163: 231.

Valiente-Banuet, A., M. Aizen, J. Alcántara, J. Arroyo, A. Cocucci, et al. 2015. Beyond species loss: the extinction of ecological interactions in a changing world. Functional Ecology, 29: 299-307.

White, A., P. Helge and A. Tijen. 2000. Philippine coral reefs under threat: the economic losses caused by reef destruction. Mar. Pollut. Bull., 40:598-605.

Wilbur, K. and G. Owen. 1964. Growth. Physiology of Mollusca. Vol I. Academic Press, New York. 473 p.

Zapata, F. 2001. Formaciones coralinas de isla Gorgona. 27-40. En: López-Victoria, m. y L.M. Barrios. (Eds.). Gorgona marina: contribución al conocimiento de una isla única. INVEMAR, Santa Marta. 160 p.

Zapata, F. and B. Vargas-Ángel. 2003. Corals and coral reefs of the Pacific coast of Colombia. 419-447. En: Cortés, J. (Ed.). Coral Reefs of Latin America. Elsevier, Amsterdam. 497 p.

Zapata, F., A. Rodríguez-Ramírez, C. Caro-Zambrano and J. Garzón-Ferreira. 2010. Mid-term coral-algal dynamics and conservation status of a Gorgona Island (Tropical Eastern Pacific) coral reef. Rev. Biol. Trop., 58: 81-94.

Zar, J. H. 1999. Biostatistical Analysis. Prentice Hall. 3rd Edition, New Jersey. 663 p. 